\title{
Measurement of Professional Value Orientation of Military Professionals
}

\author{
Zdeněk Mikulka , Ivana Nekvapilová and Jolana Fedorková \\ University of Defence, Kounicova, Brno, Czech Republic
}

Correspondence should be addressed to: Zdeněk Mikulak; zdenek.mikulka@unob.cz

Received date:20 September 2018; Accepted date:22 August 2019; Published date: 7 November 2019

Academic Editor: Sylwia Stańczyk

Copyright (C) 2019. Zdeněk Mikulak, Ivana Nekvapilová and Jolana Fedorková. Distributed under Creative Commons CC-BY 4.0

\begin{abstract}
The aim of the manuscript is to inform about the background, methodology, course, and results of research into the professional value orientation of Czech military professionals - students of the University of Defense (hereinafter UoD) military study programs - future career officers. The described research, aimed at determining the preference of values, represents an experiment. In addition to the observed value orientation, this research has been experimentally verified and, based on the results, a tool for objective determination of the military-professional value attitude of military professionals "Attitude Towards Moral Dilemma" (hereinafter ATMoD) has been designed for optimization. ATMoD is a revised inventory of value portraits of S. Schwartz's "Portrait Values Questionnaire" (hereinafter PVQ) created by authors of the manuscript for a military-focused community, focusing on the values of the so-called higher-order Conservatism (C), Openness to Change (OC), Self-Enhancement (SE) and Self-Transcendence (ST). The research sample consisted of 151 respondents, the mixed research design used PVQ inventory and ATMoD tool. Respondents' free answers in the qualitative part of ATMoD were evaluated using grounded theory. It was found that the conservative value orientation within the ATMoD tool is strengthened and there was a shift in the distribution of value profiles compared to the PVQ inventory. At the same time, research has shown the need to convert ATMoD from higherorder values to basic value types based on Schwartz's theoretical model of the relationship between motivational value types (Conformity, Tradition, Benevolence, Universalism, SelfDirection, Stimulation, Hedonism, Achievement, Power, Security) for more accurate results.
\end{abstract}

Keywords: value orientation, military professionals, value types.

Cite this Article as: Zdeněk Mikulka, Ivana Nekvapilová and Jolana Fedorková (2019)," Measurement of Professional Value Orientation of Military Professionals",The Journal of Organizational Management Studies, Vol. 2019 (2019), Article ID 907156, DOI: 10.5171/2019.907156 


\section{Introduction}

Research on value attitudes has been an object of interest to experts since the 1920s (Strmiska 2018). This is mainly due to the scientific disciplines of cultural anthropology and sociology which focus on the explanation of relationships between personality and culture, and on the identification of value types in specific types of societies and explaining the factors affecting the variability of values. In the Czech environment, value attitudes began to be surveyed from the 1980s onwards. (Strmiska 2018; Šamanová 2004; Červenka 2005). Since 2004, these studies have been carried out within the framework of the European Social Research (Vávra 2007).

A systematic survey of professional value orientation of Czech military professionals, especially in terms of methodological development of this survey, cannot be traced in the field of empirical research in the Czech environment. However, it is possible to rely on the findings of already realized foreign research studies of moral competence in the military environment (Verwijh, Hofhuis and Soeters 2007), in the environment of police schools (Visu-Petra, Borlean, Chendran and Bus 2008; Babinčák and Klimešová 2011) in security services (Norris 2005) and knowledge of domestic and foreign research among university students (Slováčková 2000; Colesante and Biggs 2001; Norris 2005).

A peculiarity of the value attitude related to the performance of the military profession is its certain internal contradiction. The military profession is a service that requires altruistic action and the ability to sacrifice to achieve higher goals and benefit the whole. At the same time, the traditional function of the armed forces is a successful armed struggle, i.e. the physical extermination of an enemy-man using legitimate and legal violence (Huntington 1957). Therefore, military executives are expected not only to perform flawlessly professionally but also to have high moral standards of conduct enabling successful identification with the soldier's social role and the ability to bear the internal value inconsistency described above.

The basic prerequisite for the targeted building of the required moral-value standards in the performance of the military profession is effective ethical education and leadership, including the ability to react to changes and shifts in the determined value orientation. Its success is conditioned by the knowledge of the process of formation of professional value orientation which is based on the results of longitudinally conceived research. This, according to the authors' previous findings, must include appropriate tools and methods for the determination of professional value orientation, initial level finding and value orientation distribution, identification of key factors influencing the process and longitudinal monitoring of professional value orientation development depending on factors such as length of service, demands, position held, etc. (Mikulka, Nekvapilová and Fedorková 2018).

Building the required moral standards cannot be done without determining the level and distribution of value orientation. Knowledge from the field of psychology shows that the main attention should be focused on the values, which, unlike the preferred ones, directly affect human behaviour and have emotional and moral influence. In contrast, preferred values are associated with human rationality, which affects the respondent's objectivity, and therefore, preferred values prove to be a less reliable factor in predicting the assumed moral-value attitude (Vávra 2007). The findings of the authors in the previous value research confirm this (Nekvapilová, Mikulka and Fedorková 2018).

In order to achieve the required objectivity, a mixed research design is the most appropriate option. The mixed design created and used by the authors includes a combination of S. Schwartz's Value Portrait 
Inventory of "Portrait Values Questionnaire" (PVQ) and a PVQ variation designed to objectively measure military-professional value orientation, the "Attitude Towards Moral Dilemma" (ATMoD). In addition to the quantitative approach, elements of qualitative research could also be used. In the case of ATMoD, the aim was to create the possibility of writing spontaneous expressions of respondents to the offered value portrait (attitude) and, thus, to specify and justify the extent of the respondent's identification or rejection with this portrait (attitude).

The aim of the manuscript is to inform about the background, methodology, course, and results of research into the professional value orientation of Czech military professionals - students of the University of Defense (hereinafter UoD) military study programs - future career officers. The described research, aimed at determining the preference of the confessed values, is an experiment helping to create a set of methods and tools for the determination of professional moral-value orientation. In addition to the observed value orientation, this research has been experimentally verified and, based on the results, a tool for objective determination of the militaryprofessional value attitude of Czech military professionals ATMoD has been designed for optimization. Its proposed optimization represents one of the outputs of this manuscript and can be used in further research and educational practice, in the field of military professional ethics and ethical leadership.

\section{Methodology}

An extensive theoretical background consisting of a plurality of theories based on various theological and philosophical approaches and further developed by a number of scientific disciplines such as sociology, cultural anthropology, psychology or moral philosophy (ethics) can be used to study the professional value orientation of military professionals.

According to Vávra (2007), values are attributes that people attribute to certain objects, situations, events or activities in connection with meeting their needs and interests. Values represent desirable, important goals in the lives of each individual and each social group. Depending on their importance, they are organized into a system that largely determines the attitudes, lifestyles, and morals of the individual (Prücha 2004), as well as the way of life, work and the level of culture of the social group (Hofstede 2001). The value system is dynamic, its dynamics are associated with variables such as gender, age, life and professional experience, a field of activity, but also the social environment and its influence.

Values have a number of important functions: they motivate to act, to meet goals, to accomplish tasks, to justify the action, to provide criteria and standards to evaluate people and events, and to influence susceptibility to phenomena. Depending on the situational context, they can play both a positive role as internal drivers for action and change and a controversial role as an internal barrier. Influencing human behaviour is directly linked to the confessed values because the confessed values have an emotional and moral influence on the individual. Intentional denial of beliefs can cause nervousness, stress, feelings of shame and guilt (Vávra 2007).

In contrast, preferred values associated with human rationality prove to be a less reliable factor in predicting actual behaviour. Repeated research confirms that, despite knowing what to do (what is right) in certain situations, there are often quite different (wrong) actions for which rational justifications are created (Vávra 2007).

It is possible to conclude from this very generalized knowledge that in the research 
of professional value orientation, it is appropriate to use a socio-psychological approach which allows capturing the mutual links between individual and group values and focusing on the set of individual values. Based on theoretical knowledge, it can be assumed that if the values required by the profession are a part of the value profile of the individual (a group of individuals), it is possible to infer the degree of interiorisation of professional values and to predict a higher degree of reliability in professional conduct.

When focusing research efforts on the values, mixed research design using a combination of quantitative research (standard questionnaire research) with qualitative research methods, e.g. observation, case study solution, etc., seems more appropriate (Hendl 2005). Based on the literature review, assessment of available testing tools usable in the Czech language mutation and previous research findings of the authors (Nekvapilová 2018), the approach of Shalom Schwartz (Schwartz and Bilsky 1987) was chosen for exploring professional value orientation. The Schwartz's approach fulfills, from the authors' point of view, four basic requirements: it is designed for the adult population, presents a holistic approach involving the psychology of values, and allows the aggregation of results to higherorder values and their generalization (Vávra 2007)

, and creates a prerequisite for the successful interiorisation of military values (Nekvapilová 2018).

Schwartz's inventory of value portraits of PVQ uses only quantitative methods, yet it captures values that are not significantly influenced by the current context and seeks to identify the values at the top of the value hierarchy and applied in various life situations (Vávra, 2007). In this concept of Shalom Schwartz and Wayne Bilski (1987, 1990), the values have five formal characteristics: they are concepts or beliefs, relate to desirable end states or behaviours, transcend specific situations, control the selection or evaluation of behaviours and phenomena, and are organized according to of relative importance - they create a certain structure. Therefore, the whole value structure of respondents must be measured, no significant value dimension should be neglected (Schwartz 1992).

Values and value profiles that are desirable for a military professional can be identified on a general level in value profiles created according to the Schwartz PVQ Value Portrait Inventory. The disadvantage of PVQ as a tool for examining military-professional values is that the PVQ inventory does not separately capture the specific values required for the military profession: responsibility and sense of duty, justice, dedication, courage, loyalty, and honour (Czech Army Doctrine 2013). At the same time, it does not make it possible to identify situational and other influences affecting the conduct in accordance with or in contradiction to these specific values. Therefore, it is necessary to supplement the PVQ with other methods and tools.

For this purpose, the authors created a specific tool called ATMoD.

\section{Research Objectives and Methods}

The aim of the research experiment was to determine the level and distribution of the value orientation of the confessed values and on the basis of the performed experiment and its results to propose a tool for optimization for objective determination of military-professional value orientation of Czech military professionals ATMoD. The realization itself consisted in comparing the distribution of value types of the so-called higher-order Conservatism (C), Openness to Change (OC), Self-Enhancement (SE) and Self-Transcendence (ST) ascertained by ATMoD in the sample with the distribution of these value types detected by the standardized PVQ tool. The following research questions were identified for this research experiment: Is there a demonstrable difference in the degree of identification and also in the distribution of higher-order value types measured by 
ATMoD compared to their measurements by PVQ? Is it possible to identify specific confessed values for the military profession by means of ATMoD? How can ATMoD be optimized, based on the findings of a research experiment?

The standardized PVQ tool is used in a 21item version. Each item is a verbal portrait of a certain value attitude (Schwartz et al. 2001). For each portrait, the respondent determines to what extent he agrees with the described person on a scale of 1 (very similar to me) to 6 (not at all similar to me). All 21 items together cover ten basic values of Schwarz's theory of values: security, conformism, tradition, independence /selfdetermination/, stimulation, self-indulgence, /hedonism/, power, success, universalism, and benevolence). Surveys in 18 countries have shown that the ten value types are welldifferentiated because the expected value structure appeared in all research files (Schwarz 2001) and the possibility of a missing value type in this structure was also ruled out. At the same time, mutual relationships between individual values types were confirmed (Schwartz 2001). Schwartz and Bilsky $(1987,1990)$ derived the content typology of ten basic value types on the assumption that values represent the three universal requirements of human existence: the requirement to meet the needs of an individual as a biological organism, the requirement to meet coordinated social interaction and the requirement to meet the need to safeguard the interests of the group.

According to Schwarz's theory of basic values, these ten basic value types are grouped into the four above-mentioned higher order value types; Conservatism (C), Openness to Change (OC), Self-Enhancement (SE) and Self-Transcendence (ST), which are filled with the basic value types as follows: Conservatism (C) is made up of the values of Security SE (self-security: harmony and stability of the individual and the security of society and relationships, conformism and tradition), Conformity CO (self-control or self-discipline in action, behaviour, etc., respect for parents and the elderly) and Tradition TR (respect, devotion and acceptance of customs and ideas, which traditions or religion offer, modesty, acceptance of devotion). Openness to change (OC) is formed by the values of SelfDirection SD (independence, freedom in Behaviour, creativity, curiosity, need for autonomy and independence), Stimulation ST (variability, stimulation, newness, life challenges) and Self-indulgence/Hedonism HE (joy, pleasure and sensual enjoyment, self-satisfaction, need for enjoyment, pleasure, delight). Self-Enhancement (SE) is saturated with Success/Achievement AC (success, recognition, personal performance, personal success based on demonstrating abilities compared to others) and Power Po (influence, power, social status, prestige, control or domination over people and resources). Self-Transcendence (ST) is fulfilled by Benevolence BE (the benefit of the people we are in everyday contact, protecting and enhancing the prosperity of people we often encounter, friendship, love, loyalty, benevolence and Universalism UN (justice, respect, tolerance and care for the good of all people and the whole of nature, social justice, equality, peace around the world, environmental protection).

A separate tool, called ATMoD (Attitude Towards Moral Dilemma), has been created to measure value profile preferences in a military-professional situation. Its core is a military-professional event containing a moral dilemma. ATMoD requires the respondent to determine the degree of personal identification with one of the four attitudes presented to the event. These attitudes were created in accordance with S. Schwartz's value theory and are contentaligned with the higher-order value types of this theory. Attitude 1 expressed conservatism, attitude 2 openness to change, attitude 3 ego-enhancement and attitude 4 overcoming yourself. A scale identical to the PVQ questionnaire was used to express the degree of the attitude, where a value of 1 (I 
can very much identify) meant unambiguous consent, without reservations, and a value of 6 (I cannot identify at all) a fundamental disagreement. In line with Lawrence Kohlberg's (1984) and George Linda's (2004) approach to measuring moral reasoning, ATMoD has been expanded and enriched with the opportunity to provide a written justification for the degree of individual attitudes, i.e. to describe the process of moral reasoning related to the choice. According to the authors, these personal statements can be considered as a valuable source of knowledge about the extent and method of identifying respondents with individual higher-order value types.

The theme of the dilemma was the real event of the tragic death of a soldier who died trying and introducing a new type of military parachute. Individual higher-order value types are expressed in the form of an evaluation of the family's response to the manner of the state-adopted solution to the entire situation, including a financial settlement with the survivors.

\section{Research Sample and Research Organization}

The research sample consisted of 151 respondents in the age range of 19-31 years. This sample was selected by random sampling (the basic set included all students of the UoD military study programs who fulfilled the following conditions: successfully passed the admission procedure to their study fields in the selected academic year, completed basic military training and fulfilled the conditions for the first year). The standardized PVQ questionnaire revealed differences in higher-order values according to the specialization (Nekvapilová 2018) in the basic sample and therefore the sample was structured according to this specialization. Other criteria were not taken into account because most respondents were classifiable into one socio-demographic category. Gender distribution was not taken into account due to the low number of women in the sample. Returnability of the questionnaire was $100 \%$. The sample included members of the three faculties of the University with different specializations in the following layout:

Table 1: Structure of the research sample

\begin{tabular}{|l|c|}
\hline & $\begin{array}{c}\text { Number of } \\
\text { Respondents }\end{array}$ \\
\hline Students of command and management branches of study & 56 \\
\hline Students of technical branches & 58 \\
\hline Medical students & 32 \\
\hline Physical education students & 5 \\
\hline Total set values & 151 \\
\hline
\end{tabular}

Source: Authors' own research

Respondents completed the ATMoD form separately instructed by an authorized person.

The administration of the form was carried out within the framework of the course Preparation in Field II, in the form of mass administration, the size of individually interviewed groups ranged from 20 to 40 respondents.
The same conditions for completing the questionnaire were ensured for each group. Data collection was anonymous, each respondent was assigned a code, which enabled subsequent comparison and correlation with results of higher order values distribution according to PVQ inventory which was surveyed separately (Nekvapilová 2018). 
The time of filling in the form was not deliberately limited, for most respondents it, ranged from 10 to 15 minutes.

\section{Results}

The overall results in Table 2 show that the differences in the measured values according to the PVQ questionnaire and the ATMoD tool were indeed found. They are more significant in the two of the monitored higher-order value profiles: Openness to Change $(\mathrm{OC})$ and Self-Enhancement (SE). In the ATMoD tool profession situation, respondents with the OC and SE identified themselves less than with the value portraits expressing these value profiles for PVQ. At the ATMoD tool profession situation, the conservative value orientation (C) slightly strengthened, and on the individual level, it was the even more noticeable.

Table 2: Descriptive statistics of value characteristics of students - military professionals

\begin{tabular}{|l|c|c|c|}
\hline & $\begin{array}{c}\text { Number of } \\
\text { Respondents }\end{array}$ & $\begin{array}{c}\text { Average } \\
\text { PVQ }\end{array}$ & $\begin{array}{c}\text { Average } \\
\text { ATMoD }\end{array}$ \\
\hline Age & 151 & 22 & 22 \\
\hline Conservatism (C) & 151 & 2.892 & 2.85 \\
\hline Openness to Change (OC) & 151 & $\mathbf{2 . 3 8 5}$ & $\mathbf{3 . 5 4}$ \\
\hline Self-Enhancement (SE) & 151 & $\mathbf{3 . 1 3 4}$ & $\mathbf{4 . 1 7}$ \\
\hline Self-Transcendence (ST) & 151 & 2.441 & 2.55 \\
\hline
\end{tabular}

Source: Author's own research

As expected, the more interesting differences in preferences were proved in dependence with the field studied. Due to the different number of respondents in each cohort, the changes were compared only within the individual cohorts.

Table 3: Descriptive statistics of value characteristics of students - military professionals according to study orientation

\begin{tabular}{|c|c|c|c|c|c|c|c|c|c|}
\hline & $\begin{array}{c}\text { Number } \\
\text { of resp. }\end{array}$ & $\begin{array}{c}\text { C } \\
\text { PVQ }\end{array}$ & $\begin{array}{c}\text { C } \\
\text { ATMoD }\end{array}$ & $\begin{array}{c}\text { OC } \\
\text { PVQ }\end{array}$ & $\begin{array}{c}\text { OC } \\
\text { ATMoD }\end{array}$ & $\begin{array}{c}\text { SE } \\
\text { PVQ }\end{array}$ & $\begin{array}{c}\text { SE } \\
\text { ATMoD }\end{array}$ & $\begin{array}{c}\text { ST } \\
\text { PVQ }\end{array}$ & $\begin{array}{c}\text { ST } \\
\text { ATMoD }\end{array}$ \\
\hline $\begin{array}{c}\text { Commanders } \\
\text { and managers }\end{array}$ & 56 & 2,85 & 2.98 & $\mathbf{2 . 2 7}$ & $\mathbf{3 . 6 4}$ & $\mathbf{3 . 0 7}$ & $\mathbf{4 . 6 0}$ & 2.38 & 2.60 \\
\hline Engineers & 58 & $\mathbf{3 . 1 7}$ & $\mathbf{2 . 8 4}$ & $\mathbf{3 . 0 0}$ & $\mathbf{3 . 8 1}$ & $\mathbf{2 . 5 0}$ & $\mathbf{4 . 4 6}$ & $\mathbf{3 . 0 0}$ & $\mathbf{2 . 4 8}$ \\
\hline $\begin{array}{c}\text { Medical } \\
\text { students }\end{array}$ & 32 & 2.79 & 2.96 & $\mathbf{2 . 3 8}$ & $\mathbf{3 . 3 1}$ & $\mathbf{3 . 0 1}$ & $\mathbf{4}$ & 2.23 & 1.93 \\
\hline $\begin{array}{c}\text { Physical } \\
\text { education } \\
\text { students }\end{array}$ & 5 & $\mathbf{3 . 5 7}$ & $\mathbf{2 . 6}$ & $\mathbf{2 . 5 3}$ & $\mathbf{3 . 4}$ & $\mathbf{2 . 8 5}$ & $\mathbf{3 . 6}$ & 3.12 & 3.2 \\
\hline $\begin{array}{c}\text { Values for the } \\
\text { whole set }\end{array}$ & 151 & 2.89 & 2.85 & $\mathbf{2 . 3 8}$ & $\mathbf{3 . 5 4}$ & $\mathbf{3 . 1 3}$ & $\mathbf{4 . 1 7}$ & 2.44 & 2.55 \\
\hline
\end{tabular}

Source: Author's own research

In the case of ATMoD's professional situation, students in technical fields have seen a stronger shift towards Conservatism (C) and
Self-Transcendence (ST) values and a deviation from the Self-Enhancement (SE) profile compared to the PVQ results, 
indicating a higher level of identification with the value specifics required by the military profession and generally desirable in the military and security environment. Surprisingly, there was a slight deviation from Conservatism(C) and SelfTranscendence (ST) among students in command branches. There was no strengthening impact on ATMoD's professional situation in this cohort compared to the PVQ results. For medical and physical education students, who together formed one cohort, the professional situation at ATMoD strengthened the profile of Self-Transcendence (ST) and decreased identification with the profiles: Openness to Change (OC) and Self-Enhancement (SE).

Only 90 out of a total of 151 submitted questionnaires could be used for the qualitative part of the research, as they contained the required verbal expressions on all four of these attitudes expressing individual higher-order value profiles. At the same time, individual statements of respondents had to meet the required quality parameters.

Due to the absence of one to three verbal statements, 26 questionnaires were excluded. On average, the most unjustified answers occurred in medical and physical education students. Further selection (elimination of 35 submitted questionnaires) was necessary due to the fact that some verbal expressions did not meet the required qualitative parameter, which was the argumentation justification of the extent respondent that identifies himself with the attitude.

Open coding carried out using grounded theory showed the necessity to concentrate on statements with the strong agreement (rating 1-2 on the scale) or, on the contrary, significant disagreement (rating 5-6 on the scale) of respondents. The following values were most common in these grounds: life, justice, organizational responsibility, individual-soldier responsibility, money (often mentioned in the sense that life cannot be replaced by them), balance (sense of proportion), loyalty, solidarity, truth, independence in thought.

\section{Conclusion}

The results confirmed that the professional situation of ATMoD had an impact on respondents' decisions. According to the results of quantitative ATMoD polling, the Conservative (C) value profile was strengthened overall over the PVQ results, confirming a higher degree of respondents' identification with the values of the military profession through ATMoD's militaryprofessional situation. The observed differences (see Table 3) were related to the specialization of respondents. Overall, it was confirmed that there was a demonstrable difference not only in the degree of identification but also in the distribution of higher-order value types measured by ATMoD compared to their measurements by PVQ. The first research question was answered in the affirmative by this finding. At the same time, the measurement of value orientation by means of a tool based on taking a position on a professionally-oriented situation has proved to be justified.

The results of qualitative questioning of ATMoD instrument confirmed that the identification of respondents with value profiles that are preferred in connection with the performance of the military profession, with Conservatism (C) and SelfTranscendence (ST). In verbal spontaneous statements, respondents were argued with values such as respect for life, justice, the responsibility of the organization and the individual, moderation, loyalty, money (most often compared to life value), balance (sense of proportion), solidarity, truth, independence of thought and responsible free decision making. These values can be considered desirable for the performance of the military profession and directly correspond to the specific values of the military profession defined by the Czech Army Doctrine (2013): responsibility and sense of duty, justice, dedication, courage, 
loyalty, and honour. This finding answered the second research question and demonstrated that ATMoD can identify specific values desirable for the military profession.

At the same time, it can be inferred from the obtained results that each of the higher-order value types measured by ATMoD can be strengthened or weakened significantly compared to their PVQ measurement. (Attitudes of respondents to statements representing individual higher-order value types varied on a wider scale in ATMoD than in PVQ). It has been shown that this fact is mainly influenced by the nature and type of the chosen military - professional situation. This finding answered the third research question and confirmed the need to optimize ATMoD by revising its current form and creating a more accurate metric.

In the original research experiment, the ATMoD tool was chosen to quantify the military-professional situation at the level of higher-order value types: Conservatism (C), Openness to Change (OC), Self-Enhancement (SE) and Self-Transcendence (ST), with the necessity of qualitative justification of the degree of personal identification with the offered attitudes. The results and their interpretation have shown the need to optimize ATMoD in such a way that the quantitative assessment of the militaryprofessional situation includes a more detailed metric representing the assessment of individual attitudes, expressing the ten basic value types: Security (SE), Conformity (CO), Tradition (TR), Self-Direction (SD), Stimulation (ST), Self-indulgence/Hedonism (HE), Success/Achievement (AC), Power (PO), Benevolence (BE), and Universalism (UN).

At the same time, the results and their interpretation confirmed the need to optimize the qualitative part of ATMoD. It has been shown that in order to assess individual attitudes expressing the value types of Schwarz's theory of values, it is necessary to add a requirement that the respondent freely assess to what extent this particular attitude complies with the specific values of the military profession defined by the Czech Army Doctrine (2013): sense of duty, justice, dedication, courage, fidelity, and honour.

\section{Acknowledgment}

The research activity originated in connection with the specific research project "Moral Integrity and Personality of a Member of the Army of the Czech Republic" and now continues within the solution of the longterm project of the organization development entitled "The Development of Social Competencies of The Soldier - Leader ".

\section{References}

1. Babinčák, P., Klimešová, M. (2011) „Morálna kompetencia a hodnoty budúcich policajtov." Sociálne procesy a osobnost', 2010. Zborník príspevkov. ISBN: 978-80-89524-013, SpÚ SAV, Košice, Slovakia, 24-3.

2. Colesante, R. and Biggs, D. (2001) „A controversy about the measurement of moral development: Stage preference or moral consistency?" Proceedings of the Association for Moral Education Conference, 25 - 27 October 2001, St. Louis, USA,

3. Červenka, J. (2005) „Hodnotové orientace v naší společnosti," Naše společnost , 3 (2), 68.

4. Doktrína Armády České republiky (2013), Ministerstvo obrany České republiky Vojenský historický ústav, Praha, Czech Republic.

5. Hendl, J. (2005) Kvalitativní výzkum. Portál, Praha, Czech Republic.

6. Hofstede, G. (2001) Culture's Consequences: Comparing Values, Behaviors, Institutions and Organizations across Nations. Thousand Oaks: Sage. 
7. Huntington, S. P. (1957) The Soldier and the State. Harvard University, Press, Harvard. 8. Kohlberg, L. (1984). Essays on moral development / the nature and validity of moral stages. Vol. 2, Vol. 2. San Francisco, Harper \& Row. San Francisco.

9. Lind, G. (2004) "The Meaning and Measurement of Moral Judgment Competence: A Dual-Aspect Model." Contemporary Philosophical and Psychological Perspectives on Moral Development and Education, Hampton Press, Cresskill, 185-220.

10.Nekvapilová, I., Mikulka, Z. and Fedorková, J. (2018). "Probe into the Professional Value Orientation of Military Professionals." Proceedings of the 32nd International Business Information Management Association Conference (IBIMA). ISBN: 978-0-9998551-1-9, 2018, Seville, Spain, 3400-3409.

11.Mikulka, Z., Nekvapilová, I. and Fedorková, J. (2018). “Teaching Professional Ethics in the System of Military Tertiary Education with the use of Adventure Education". Proceedings of the ICERI2018. ISBN: 978-84-09-05948-5, 2018, Seville, Spain, 2357-2366.

12.Nekvapilová, I. (2018) "Value profiles of members of the Army of the Czech Republic". Grant Journal, 7(1), 65-70.

13.Norris, G. (2005) The authoritarian personality in the 21st century. [Thesis]. Gold Coast, QLD : Bond University.

14.Průcha, J. (2004) Interkulturní psychologie. Portál, Praha, Czech Republic.

15.Schwartz, S. H. and Bilsky, W. (1987) "Toward a psychological structure of human values". Journal of Personality and Social Psychology, 53, 550-562.

16.Schwartz, S. H. et al. (2001) "Extending the cross-cultural validity of the theory of basic human values with a different method of measurement". Journal of Cross-cultural Psychology, 32, 519-542.

17.Schwartz, S. H. (2001) "A proposal for measuring value orientation across nations". The European social survey core questionnaire development. ESS central co-ordinating team. 241-296.

18.Slováčková, B. (2001) "Morální kompetence a morální postoje u studentů lékařské fakulty Univerzity Karlovy v Hradci Králové". [Online]. Psychiatrie, 5, 4. [cit. 2019-02-13].

http://www.tigis.cz/PSYCHIAT/PSYCH201/ $\underline{04 . h t m}$

19.Strmiska, Z. (2018) „Výzkum hodnot“. [Online]. Sociologická encyklopedie. [cit. 2019-02-13].

https://encyklopedie.soc.cas.cz/w/V\%C3\%B Dzkum hodnot

20.Šamanová, G. (2004) „Hodnotové orientace". [Online]. Centrum pro výzkum veřejného mínění. [cit. 2019-02-13]. https://cvvm.soc.cas.cz/media/com form2co ntent/documents

21.Vávra, M. (2007) Hodnotový portrét evropských zemí: Srovnávací analýza $\mathrm{s}$ použitím přístupu Schaloma Schwartze. CESES FSV UK, 2007. Studie CESES, 2/2007, Praha, Czech Republic.

22.Verweij, D., Hofhuis, K. and Soeters, J. (2007) „Moral Judgement within the Armed Forces," Journal of Military Ethics, 6 (1), 1940.

23. Visu-Petra, G., Borlean, C., Chendran, L. and Bus, I. (2008) „An investigation of antisocial attitudes, family background and moral reasoning in violent offenders and police students", Cognition, Brain, Behavior, an Interdisciplinary Journal, 12 (2), 143-159. 